\title{
Erratum: Ichthyofauna of the hydrographic basin of the Chasqueiro Stream (Mirim Lagoon system, southern Brazil): generating subsidies for conservation and management
}

In the manuscript "Ichthyofauna of the hydrographic basin of the Chasqueiro Stream (Mirim Lagoon system, southern Brazil): generating subsidies for conservation and management" with DOI code number 10.1590/16760611-BN-2015-0006 published at Biota Neotropica 15(4): e0006

Where you read:

In 1977, a dam was constructed to prevent the entry of salt water into the region of Mirim Lagoon, the main water source used for agriculture, particularly for rice cultivation (Burns et al. 2006, Mouchet et al. 2012, Corrêa et al. 2015).

\section{Please read:}

In 1977, a dam was constructed to prevent the entry of salt water into the region of Mirim Lagoon, the main water source used for agriculture, particularly for rice cultivation (Burns et al. 2006, Corrêa et al. 2015). 